Bouckaert, G., Van de Walle, S. \& Kampen, J. K. (2005). Potential for comparative public opinion research in public administration. International Review of Administrative Sciences, 71 (2): 229-240.

\title{
Potential For COMPARATIVE PUbLIC OPINION RESEARCH IN PUbliC
}

\author{
ADMINISTRATION \\ Geert BOUCKAERT, Steven VAN DE WALLE and Jarl K. KAMPEN ${ }^{1}$
}

\begin{abstract}
The public administration and public services have always taken a marginal place in the political scientists' behavioural research. Public administration students on the other hand tend to focus on political and administrative elites and institutions, and largely ignored citizens in comparative research. In this article we make a plea for international comparative research on citizens' attitudes towards the public administration from an interdisciplinary perspective. Available international survey material is discussed, and main trends in empirical practice and theoretical approaches are outlined, especially those with a potential impact on public sector reform.
\end{abstract}

Keywords: trust in government, satisfaction with service delivery, public opinion, administrative culture, survey research.

\footnotetext{
${ }^{1}$ Geert Bouckaert is Director, and Steven Van de Walle and Jarl K. Kampen are researchers at the Public Management Institute, Katholieke Universiteit Leuven, Belgium.
} 


\section{Introduction}

Trust in the civil service is extremely low in Greece and Italy, while the Austrians and Luxemburgers have the highest level of trust (Spring 2002 Eurobarometer). Public administrations often suffer from a very negative image among the population, which is, according to political discourse at least, a major contributing factor to citizens' distrust in government (Van de Walle and Bouckaert, 2003). Consequences of this distrust with regard to the functioning of states and administrations are said to be manifold: failing public sector recruitment, tax evasion and declining law abiding behaviour, shifts in the political party landscape, or even political earthquakes affecting the entire political constellation, increased need for the public administration to invest in enforcement and control mechanisms, difficulties to reach less well off groups with government programmes etc. Despite the intensity by which these causal relations are proclaimed and repeated, empirical proof is often hard to find.

This distrust, be it real or not, seems to be a factor that is present in most countries. Many government administrations have therefore launched projects to measure, map and explain their citizens' attitude towards the public administration. Distrust in government has been the topic of much research by political scientists and sociologists, but there is little international comparative research focusing on the image of the public administration.

This article outlines the challenges and possibilities for international comparative research on citizen attitudes towards the public administration. Customer satisfaction with specific services has been studied quite intensively, but general citizen attitudes towards the public administration at large do not seem to be popular among researchers. Some research maps these general attitudes, but attention for the values 
and beliefs underlying these attitudes is weak to absent. This article provides an inventory of available data for studying the public opinion towards the public administration. Our focus will be on European countries, as it is for these countries that the bulk of empirical cross-national data is available. Most suggestions are valid however for other countries and regions as well.

\section{A disregard for citizens in administrative culture research}

Research on administrative cultures has thus far primarily focused on institutions and actors within the system (top civil servants, politicians). Differences in citizen attitudes are seldom taken into account. A Dane's relation to, and appreciation of, his administration is not the same as that of a Portuguese. Different concepts of administration exist, certain guiding principles are considered less or more important and some national administrations are trusted more than others. All this indicates a need for systematic international comparative research into administrative culture from a citizen perspective. Research on administrative cultures should be built on at least three blocks:

- Institutions

- Political and administrative elites

- Citizens

While most of the research has focused on institutions and political-administrative elites, in this article we will focus on the third building block: the citizens. In a number of cases citizens have been the object of study, be it that research was often limited to certain aspects of the public administration, such as local government (Rose, 1999; Rose and Pettersen, 2000). 
The need for thorough research on citizens' opinion about the public administration has been identified on several occasions, but this did not give rise to a real research tradition. Rainey (1996) even designed an ideal framework for survey research on public opinion towards the civil service, and Soós (2001) explicitly included citizens' political culture into his research design on indicators of local democratic governance. Derlien, in his review article on the state of comparative administration research until 1992, did not even mention a single study that had the citizens' relationship to their administration as a topic. This should not come as a surprise, as he noted that comparative analysis in all fields of public administration was still the exception rather than the rule (Derlien, 1992: 297).

Most research on administrative and political cultures with regard to public administrations has focused on political and administrative elites (Aberbach, Putnam, and Rockman, 1981; Rouban, 1995) by interviewing civil servants (Bekke, Perry, and Toonen, 1996; Page and Wright, 1999), municipal CEOs (Klausen and Magnier, 1998), civil servants in the European administrations (Hooghe, 2002), and majors (Soós, Tóka, and Wright, 2002), etc. Still other studies tried to compare politicaladministrative institutions (Peters, 1989). These studies reveal that considerable differences between countries exist, and therefore the place of the public administration within the state differs depending on the political, constitutional and cultural situation (Coombes, 1998; Stillman, 1999). There is no such thing as a universal concept of the administrative state. Even more, the conception of the state itself differs widely. Few efforts are made to distinguish between state and public administration. Therefore, the exact relation between state and public administration remains fuzzy. In the US approach, the public administration makes the state, as the 
state is seen as a problem-solver, while in Europe it is the state that shapes the public administration, in a more legalistic tradition (Kickert and Stillman II, 1996). There is no reason why these differences cannot be observed in citizens' minds as well, or why they would not be reflected in citizens' preferences and in their conceptualisation of the public administration within the state.

When doing empirical research on citizens' attitudes towards the public administration and on their conceptualisation of the administrative state, researchers' attention goes to organising new opinion surveys all too often, and there is little enthusiasm for secondary analysis of existing data. The reasons behind this are easy to identify.

- Research on public administration was not the aim of most surveys when they were organised (European Values Study is a sociological survey, Eurobarometer has a policy support function), which means these sources are often unknown to public administration researchers.

- Because of the (political) sociological nature of these surveys, most contain a limited number of items on public administrations and public services.

- In many cases, accessibility problems hinder researchers. Even though numerous data-files exist, it is often very difficult to trace them and to combine or merge them. Even more problems exist in evaluating the quality of existing data-files.

- Historic data or data on general evolutions or values that may help to explain public administration phenomena are often of interest for 'pur sang' public administration researchers only. The work of most researchers is closely related to requirements of the sponsoring organisation or government, who are often mainly 
interested in new and recent material that has immediate relevance for policy or management.

Despite of all these drawbacks, there already is a huge potential for research on citizens' attitudes towards the public administration. The remainder of this article consist of three parts. First, we identify existing research on citizens' attitude towards the public administration: What is citizens' image of the public administration, what about levels of trust in the civil service? Secondly, we list and describe a number of valuable surveys that offer promising prospects for comparative research but which have remained under explored by public administration researchers. Finally, we map a number of trends in the empirical approach to citizens' attitude towards the administration, theoretical explanations for these attitudes and the impact of these 'new' issues on the public sector reform agenda.

\section{Citizens' image of the public administration}

The citizen has not been an object of study in public administration from the very start, due to the discipline's early focus on organisation studies and politicaladministrative relations. Things have changed in the meantime, but attention for subjective data such as opinion data has always been, and still is, limited in comparison to the widespread use of performance indicators in public administration research. Still, a number of studies with a theoretical approach to public opinion towards the public administration have been written (Ott and Shafritz, 1995; Rainey, 1996). Recently we observe an increased use of opinion data in public administration. In most cases, however, this use is limited to the national context: Repeated citizen assessments of the Israeli public sector (Vigoda and Yuval, 2001), analysis of Spanish 
public opinion data on the public sector (del Pino, 2002), Finnish citizens' trust in their ministries (Harisalo and Stenvall, 2002), Norwegians' trust in government (Christensen and Laegreid, forthcoming), and citizen-local government relations in several Central-European countries (Swianiewicz, 2001).

Many governments are escalating their efforts to monitor citizens' attitudes towards government and the public administration: Trust and satisfaction indicators have permeated the Finnish public sector (Alam, 2002; Holkeri and Nurmi, 2002). The Danish Ministry of Finance organised a survey on citizens and the public sector in 1998 (The Danish Ministry of Finance, 1998). The Belgian Federal government had an instrument for measuring satisfaction with and trust in the federal public services (Legrand and Staes, 1998). At the Flemish level, the Administration for Planning and Statistics has organised an annual survey since 1996 covering policy issues, but also attitudes towards government (www.vlaanderen.be/aps), and we recently did a largescale survey on citizen attitudes towards the public administration (www.kuleuven.ac.be/io/trust). In the Netherlands, a 'Belevingsmonitor' was launched in 2003 as a monthly survey on trust in government. Recently however, the political desirability of the project was a matter of dispute, especially after a number of results that were not exactly flattering for government were published (x, 2003). In the UK, the People's Panel has been a valuable source of information (www.cabinet-office.gov.uk/servicefirst), and the Cabinet office prepared several documents and organised seminars on satisfaction with public services at all levels of government (Moore, Clarke, Johnson, Seargeant, and Steele, 1998; Donovan, Brown, and Bellulo, 2001). At the local level, the Audit Commission launched a broad project on trust and corporate governance in public institutions, including an opinion survey 
(Audit Commission, 2003; Audit Commission and MORI Social Research Institute, 2003). As part of the Review of Public Administration by the Northern Ireland Executive (www.rpani.gov.uk), a number of omnibus surveys have been organised to find out the public's views and experiences of public services in Northern Ireland (Knox and Carmichael, 2003).

The practice seems to be best established in the Canadian government (Sims, 2001). All kinds of surveys (citizens, customers, employees) are theoretically related into a single service value chain. In just some years, a government tradition of regular largescale surveys has emerged. The bi annual Citizens First survey deals with what citizens think about the services they receive, while the Listening to Canadians surveys deal with government communication and measures Canadians' views on public policy priorities. It also outlines how the Government of Canada serves Canadians in response to those priorities (www.communication.gc.ca).

Several non-profit initiatives have measured citizens' attitudes towards public service(s) at large in the USA, such as PEW (The Pew Research Center for the People and the Press, 1998) and the Council for Excellence in Government's and Ford Foundation's Partnership for Trust in Government (Council for Excellence in Government, 1999). In 1999, the Panel on Civic Trust and Citizen Responsibility, with Paul Volcker as chairman, issued its 'A government to trust and respect: rebuilding citizen-government relations for the $21^{\text {st }}$ century'.

The lack of data makes it difficult to map trends in Australia, but concerns about trust certainly exist, as is shown by discussions at the Office of the Auditor General of Western Australia on public confidence in the public sector (Ryan, 2000). In New Zealand, Barnes \& Gill in 2000 wrote a Working Paper for the State Services 
Commission, entitled 'Declining government performance? Why citizens don't trust government'.

Scattered initiatives exist on the African continent (African Training and Research Centre in Administration for Development, 1998; Public Service Commission, 2003), or in Latin America (Payne, Zovatto G., Carillo Flórez, and Allamand Zaval, 2002).

These government initiatives are real goldmines for data, but remain often unknown to researchers. Unfortunately, international comparison remains very difficult with these national-level initiatives, due to a large variety of survey methods and survey content.

\section{Available data for international comparison}

There has always been more interest for collecting new data than for consolidating and analysing existing data. This means that many survey data have not (yet) been 'discovered' by public administration researchers, and that items on the public administration, public services and civil servants remain thus far largely unexplored. Many of these surveys have been designed for other purposes, often in the field of (political) sociology, what explains the limited use by public administration scholars.

The table provides an inventory of surveys that are available to public administration scholars who want to do research on citizen attitudes towards the public administration. Condition for inclusion in the list is that the survey covers at least 3 European countries, and that it contains a fair number of items dealing with the public administration. The list is not meant to be comprehensive. It mainly focuses on European and North American countries, as it is this region for which most material is 
Potential for comparative public opinion research in public administration 10

available $^{2}$. Apart from this series of surveys among the general population, numerous surveys exist among selected groups, often business people, civil servants, politicians or experts. The World Bank has compiled a good overview of these studies and surveys (Kaufmann, Kraay, and Zoido-Lobaton, 2002), which is also available on its website.

2 For other countries, some different data-sources exist: Global Barometer (www.globalbarometer.org), Afrobarometer (www.afrobarometer.org), East Asia Barometer (http://eacsurvey.law.ntu.edu.tw), Latinobarómetro (www.latinobarometro.org) etc. Especially in Latin America, a number of in-depth studies have already been completed (Adserà, Boix, and Payne, 2000; Payne et al., 2002). 
Table 1: Overview of data sources on public opinion towards the public administration

\begin{tabular}{|c|c|c|c|c|}
\hline Source & Period & Coverage (respondents, countries) & Useful items & URL \\
\hline $\begin{array}{l}\text { Eurobarometer (European } \\
\text { Commission) }\end{array}$ & 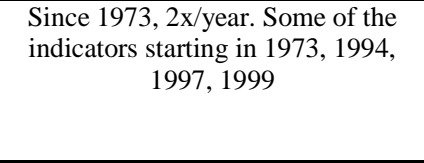 & Approx. 1000 in all EU countries & $\begin{array}{c}\text { Trust in institutions; satisfaction with } \\
\text { democracy } \\
\text { Special reference to Services of general interest } \\
\text { in EB } 53 \text { and 58. In-depth survey of public } \\
\text { services in EB } 47 \text {. }\end{array}$ & $\frac{\frac{\mathrm{http} / / \text { europa.eu.int/comm/public opinio }}{\mathrm{n} /}}{}$ \\
\hline $\begin{array}{l}\text { Candidate Countries Eurobarometer } \\
\text { (previously Central and Eastern } \\
\text { Eurobarometer - EC) }\end{array}$ & Since autumn 1990 , yearly & $\begin{array}{l}\text { Approx. } 1000 \text { in each EU Candidate } \\
\text { country }\end{array}$ & Trust in institutions; satisfaction democracy & $\frac{\text { http://europa.eu.int/comm/public opinio }}{\underline{\mathrm{n} /}}$ \\
\hline $\begin{array}{l}\text { Special Eurobarometers (European } \\
\text { Commission) }\end{array}$ & $2000 \& 2002$ & Approx. 1000 in each EU country & Services d'intérêt général (2000 \& 2002) & $\frac{\text { http://europa.eu.int/comm/public_opinio }}{\underline{\mathrm{n} /}}$ \\
\hline $\begin{array}{l}\text { Europinion, Continuous Tracking } \\
\text { Survey (European Commission) }\end{array}$ & October 1996 & Approx. 800 per EU country & $\begin{array}{l}\text { Special Europinion: European Public opinion } \\
\text { towards public services }\end{array}$ & $\begin{array}{c}\frac{\text { http://europa.eu.int/comm/public_opinio }}{\underline{\mathrm{n} /}} \\
\text { (n) }\end{array}$ \\
\hline European Values Study & $1981,1990,1999 / 2000$ & $\begin{array}{c}32 \text { countries in last wave, approx 900- } \\
3600 \text { per country }\end{array}$ & $\begin{array}{c}\text { Confidence in institutions, satisfaction } \\
\text { democracy, technocracy \& democracy, } \\
\text { leadership, civic duties \& values, evaluation } \\
\text { 'system of governing' }\end{array}$ & www.europeanvalues.nl \\
\hline World Values Survey & $1981,90-91,95-98,99-01$ & Up to 80 societies, $\min . n=1000$ & $\begin{array}{c}\text { Confidence in institutions, satisfaction } \\
\text { democracy, technocracy \& democracy, } \\
\text { leadership, evaluation system of governing \& } \\
\text { leaders }\end{array}$ & www.worldvaluessurvey.org \\
\hline $\begin{array}{l}\text { European Social } \\
\text { Survey }\end{array}$ & Two-yearly, first in 2002, & $\begin{array}{l}\text { Min. } 1500 \text { per country, } 24 \text { European } \\
\text { countries }\end{array}$ & $\begin{array}{c}\text { Trust in institutions, satisfaction way } \\
\text { government works, satisfaction democracy, } \\
\text { functioning education \& health care, civic } \\
\text { duties }\end{array}$ & www.europeansocialsurvey.org/ \\
\hline $\begin{array}{l}\text { ISSP: International Social Survey } \\
\text { Programme }\end{array}$ & $\begin{array}{c}\text { Role of Government Module } \\
\text { (included in national surveys) 1985, } \\
1990, \pm 1995,2006 \\
\end{array}$ & $\begin{array}{l}23 \text { countries in latest Role of } \\
\text { government module, of which } 16 \\
\text { European, } n=\text { approx } 1000 / \text { country }\end{array}$ & $\begin{array}{l}\text { Government regulation, government spending } \\
\text { priorities, obeying laws, trust civil servants, } \\
\text { satisfaction democracy, taxes, privatisation }\end{array}$ & www.issp.org \\
\hline $\begin{array}{l}\text { Voice of the People (World Economic } \\
\text { Forum) }\end{array}$ & 2002 & $\mathrm{~N}=36000,47$ countries & Trust in the institutions & www.voice-of-the-people.net/ \\
\hline $\begin{array}{l}\text { Readers' Digest Trusted Brands } \\
\text { Survey }\end{array}$ & $2001,2002,2003,2004$ & $\begin{array}{c}18 \text { European countries, } \mathrm{n}=27692 \text {, mail } \\
\text { survey }\end{array}$ & $\begin{array}{c}\text { Confidence in policies, professions and } \\
\text { institutions }\end{array}$ & www.rdtrustedbrands.com/ \\
\hline Readers' Digest Eurodata & 1969,1990 & $\begin{array}{l}\text { Netherlands, Belgium, Luxembourg, } \\
\text { France, Germany, England, Italy } \\
\text { N=4919 in } 1969 \\
17 \text { European Countries. N=22339 in } \\
\text { ' } 90 ;\end{array}$ & Confidence in Institutions, civic duties & \\
\hline
\end{tabular}




\begin{tabular}{|c|c|c|c|c|}
\hline $\begin{array}{l}\text { International Crime Victim Surveys } \\
\text { (ICVS) }\end{array}$ & $1989,1992,96 / 97,00 / 01$ & $\begin{array}{c}14 \text { countries in } 1989.1000-2000 \\
\text { households, CATI or face-to-face. Now } \\
56 \text { countries }\end{array}$ & $\begin{array}{c}\text { Police helpfulness, is police doing a good job in } \\
\text { controlling crime, satisfaction police response, } \\
\text { experience of corruption by government or } \\
\text { public official }\end{array}$ & www.unicri.it/icvs/index.htm \\
\hline New Democracies Barometer (NDB) & $\begin{array}{c}\text { Five rounds: } 1991,1992-93,1993- \\
94,1995,1998\end{array}$ & $\begin{array}{c}\text { Belarus, Bulgaria, Croatia, Czech } \\
\text { Republic, Hungary, Poland, Slovenia, } \\
\text { Slovakia, Romania, Ukraine, Serbia }+ \\
\text { Montenegro, partly also in Austria, } \\
\text { Germany, Moldova, total n 8-12000 for } \\
\text { each round and Austria. } \\
\end{array}$ & $\begin{array}{c}\text { Evaluation of how government works + } \\
\text { comparison with previous regime, trust in } \\
\text { institutions }\end{array}$ & www.cspp.strath.ac.uk/ \\
\hline New Baltic Barometer (NBB) & $1993,1995,1996,2000$ & Estonia, Latvia, Lithuania, & & www.cspp.strath.ac.uk/ \\
\hline $\begin{array}{l}\text { New Europe Barometer Omnibus } \\
\text { Survey (NEB) }\end{array}$ & 2001, previously NBB \& NDB & $\begin{array}{c}\text { Bulgaria, the Czech Republic, Hungary, } \\
\text { Estonia, Latvia, Lithuania, Poland, } \\
\text { Romania, Slovakia and Slovenia, total } \\
\mathrm{n}=11012 \\
\end{array}$ & $\begin{array}{l}\text { Satisfaction democracy, Evaluation of how } \\
\text { government works + comparison with previous } \\
\text { regime, trust in institutions, corruption }\end{array}$ & www.cspp.strath.ac.uk/ \\
\hline Opinion polls & Continuous & $\begin{array}{c}\text { Wide range of public opinion surveys, } \\
\text { some have been conducted in several } \\
\text { countries e.g. Gallup Brain: database of } \\
\text { public opinion surveys by Gallup since } \\
\text { 1935; CBOS (Poland) on trust in } \\
\text { institutions in Poland, Czech republic } \\
\text { and Hungary } \\
\end{array}$ & & \\
\hline European Election Study (EES) & $\begin{array}{l}1979,1984,1989,1994,1999 \text { (on } \\
\text { the occasion of elections for the } \\
\text { European Parliament). Before } 1999 \\
\text { integrated in Eurobarometer. }\end{array}$ & $\begin{array}{l}\text { EU countries, } n=500 \text { or } 1000 \text { (300 in } \\
\text { Lux.). CATI }\end{array}$ & $\begin{array}{l}\text { Policy in integration, immigration, economy, } \\
\text { and environment: what level of government } \\
\text { should do it, should government should it? } \\
\text { Satisfaction with this policy. Satisfaction with } \\
\text { democracy, evaluation of government's record }\end{array}$ & $\begin{array}{l}\text { http://shakti.trincoll.edu/ mfrankli/EES. } \\
\text { html }\end{array}$ \\
\hline Election studies & $\begin{array}{l}\text { Continuous. Long tradition in some } \\
\text { countries, rather recent in others }\end{array}$ & $\begin{array}{l}\text { Organised in many countries, but no } \\
\text { harmonised instrument. }\end{array}$ & $\begin{array}{c}\text { For an overview of studies in some EU } \\
\text { countries, see (Mochmann, Oedegaard, and } \\
\text { Mauer, 1998) }\end{array}$ & \\
\hline
\end{tabular}


The road ahead: Challenges for international comparative research on citizens' attitudes towards the public administration and for policy

We pleaded for more attention to citizens' attitudes towards the public administration, as this is an often-neglected factor in public sector reform and in public administration research. Only by taking these attitudes into account, public sector reform may avoid backlash, and, ultimately, failure. In the research on citizens' attitudes towards the public administration and trust in government, there are number of trends, both in the empirical practice and in theoretical approaches to the issue.

\section{Trends in empirical practice}

From an elite-model to a user-based model. Researchers on administrative culture and public administration researchers have mainly focused on institutions and on political and administrative elites. Organising broad citizen surveys was left to sociologists and behavioural political scientists. Recently, attention for citizen surveys is on the rise.

From disconnected surveying to an integrated approach. Surveying is becoming more common in public administrations and in the public administration research community, but all too often questionnaires are designed on an ad hoc basis. This is due to the absence of internationally recognised and tested scales, as they exist in psychology, sociology and political science, and to the nature of most of these surveys, which are often commissioned by governmental bodies with a very specific aim in mind.

Increased use of opinion data in the administration and in public administration research. Not only measurement of citizens' trust is increasing, but also the use of 
these in administrations. Data collection is gradually moving beyond the classic customer surveying. Whereas these indicators were used anecdotally and symbolically in the past, they are now gradually being integrated into the policy-process. Still, problems persist in harmonising the administration's demand for fast, policy-relevant analysis and researchers preference for in-depth nuanced scrutiny.

In research, thorough exploitation of this data still has to take off. Administrations tend to provide funding for the collection of new data, but they hardly ever commission research that analyses existing data. This under-analysis is especially striking when we compare it to surveys in political science or sociology, where the same data is being analysed by large groups of researchers. In public administration, methods of analysis remain rather basic, and there is a need to go beyond the mere frequencies and cross-tabulations, and a critical approach to data-quality is urgently needed.

Relating performance data to perceptions. Over the past few decades, various research has been done comparing objective quality indicators and subjective perceptions. Also, it was often thought that perception data (e.g. satisfaction with local services) could be used in lieu of performance indicators. The availability of perception data at the more general public administration level will in the future allow for comparing objective quality and process indicators to levels of satisfaction with the public administration and trust in government.

\section{Trends in theoretical approaches}

The need for theoretical innovation. There is considerable empirical fragmentation in research on trust. A convergence of the means and methods of data-collection should 
eventually lead to innovative theoretical approaches. Thus far, we have seen that there has been little innovation in explanatory models for citizens' attitudes towards the public administration. Few have moved beyond the explanations, or rather observations, that have been put forward by Katz, Gutek et al. in 1975 or Goodsell in 1983 (Katz, Gutek, Kahn, and Barton, 1977; Goodsell, 1983). Predominant values that lie at the core of attitudes have remained a blind spot in research. Research should go beyond merely mapping trends and evolutions in citizens' or users' opinions on the administration, and should try to look for explanations.

Crossing boundaries: increasing interdisciplinarity. Approaching citizens' attitudes towards the public administration from a multitude of perspectives includes questioning the rational paradigm. Satisfaction with public services does not only result from the quality of services. An exclusively public administration research approach is insufficient, since it tends not to look for explanations for these attitudes beyond the administration or the administration-citizen encounter itself.

Different conceptions of the state. Cross-national or cross-cultural comparisons of citizens' attitudes towards the public administration often disregard that the mental concept of 'government', 'state' or 'public administration' does not necessarily refer to the same objective basis. To know how citizens evaluate the public administration, we first need to know what citizens see as public administration, and how public administration is seen in relation to the State (l'état). The place of the public administration in the concept of government or the State remains one of the most important issues for public administration students (Coombes, 1998:32; Rockman, 1992). 


\section{Trends in public management reform}

From public management reform to governance reform. Evolutions and trends reach beyond research and academic besognes. They even reach beyond government itself. A citizen-centred, or rather society-centred logic, replaces a government-centred one, and government reform is just one aspect in governance reform. We find similar concerns for confidence building in the upsurge of corporate governance. Citizens' attitudes towards government and the public administration may therefore be related more to trends in society rather than to trends in government.

From rational public sector reform to creativity. An improvement of public services will not necessarily lead to a more favourable citizen attitude towards the public administration. Good governance, congruence between citizens' wishes and government policy, and a well-functioning administration could, but do not necessarily have to, result in satisfied citizens. Conflicting priorities and demands are just one element in explaining this phenomenon. Rational decision-making and policy may have its limits. Creativity is needed, with communication about reforms as a key element. Governing is not only about answering demands, but also about shaping these demands. A great deal of social engineering is required.

\section{Conclusion}

The public administration and public services have always taken a marginal place in the political scientists' behavioural research. Public administration students on the other hand tended to focus on elites and institutions and largely ignored citizens in comparative research. Policy-makers often consider themselves close enough to 
citizens to know their complaints, aspirations and thoughts. Not only attention for citizens' opinion towards the public administration, but also international comparative research on this issue will have to move to the core of future research efforts. There are, however, a number of requirements for this research strategy to work. Interdisciplinarity and co-operation are key elements for this success. Studying citizen attitudes requires teams of sociologists, political scientists and psychologists, often even supplemented by anthropologists and historians. Methodological investments in this type of research are substantial, but considerable experience exists in other disciplines. Progress can only be made by standardising research and survey instruments.

\section{Reference List}

Aberbach, J. D., Putnam, R. D., \& Rockman, B. A. (1981). Bureaucrats \& politicians in Western democracies. Cambridge: Harvard University Press.

Adserà, A., Boix, C., \& Payne, M. (2000). Are you being served? Political accountability and quality of government. Inter-American Development Bank Research Department Working Paper 438.

African Training and Research Centre in Administration for Development (1998). Citizens' perception of the role of public administration and their assessment on the public services.

Alam, M. (2002). Quality, satisfaction and trust indicators in the Finnish central government organisations. Paper prepared for the Annual Conference of the European Group of Public Administration, Study Group on productivity and quality in the public sector, Potsdam, 4-7 September.

Audit Commission (2003). Corporate governance: Improvement and trust in local public services. Public Sector Management Paper. 
Barnes, C., \& Gill, D. (2000). Declining government performance? Why citizens don't trust government. New Zealand: State Services Commission.

Bekke, H. A. G. M., Perry, J. L., \& Toonen, T. A. J. (eds.) (1996). Civil service systems in comparative perspective. Bloomington: Indiana University Press.

Christensen, T., \& Laegreid, P. (forthcoming). Trust in government: The relative importance of service satisfaction, political factors and demography. Public Performance and Management Review.

Coombes, D. (1998). The place of public management in the modern European State. In T. Verheijen and D. Coombes (eds.).Innovations in public management: perspectives from East and West Europe (pp.8-38). Cheltenham: Edward Elgar.

Council for Excellence in Government (1999). America unplugged: Citizens and their government.

del Pino, E. (2002). Las actitudes de los ciudadanos hacia las administraciones, las politicas y los servicios publicos en espana: Tesis Doctoral. Madrid: Universidad Complutense de Madrid.

Derlien, H.-U. (1992). Observations on the state of comparative administration research in Europe rather comparable than comparative. Governance, 5(3): 279-311.

Donovan, N., Brown, J., \& Bellulo, L. (2001). Satisfaction with public services: a discussion paper. London: Performance and Innovation Unit.

Goodsell, C. T. (1983). The case for bureaucracy: a public administration polemic. Chatham: Chatham House Publishers Inc.

Harisalo, R., \& Stenvall, J. (2002). Citizens' trust in government. Paper presented at the Annual Conference of the European Group of Public Administration, Study Group on productivity and quality in the public sector, Potsdam, 4-7 September .

Holkeri, K., \& Nurmi, J. (2002). Quality, satisfaction and trust in government - Finnish case. Paper presented at the Annual Conference of the European Group of Public Administration, Study Group on productivity and quality in the public sector, Potsdam, 4-7 September.

Hooghe, L. (2002). The European Commission and the integration of Europe: images of governance. 
Potential for comparative public opinion research in public administration 19

Cambridge: Cambridge University Press.

Katz, D., Gutek, B. A., Kahn, R. L., \& Barton, E. (1977). Bureaucratic encounters: a pilot study in the evaluation of government services. Ann Arbor: Institute for Social Research.

Kaufmann, D., Kraay, A., \& Zoido-Lobaton, P. (2002). Governance matters II: Updated indicators for 2000/01. World Bank Policy Research Working Paper 2772.

Kickert, W., \& Stillman II, R.. (1996). Changing European states; changing public administration: Introduction. Public Administration Review, 56(1): 65-67.

Klausen, K. K., \& Magnier, A. (eds.) (1998). The anonymous leader: appointed CEOs in Western local government. Odense: Odense University Press.

Knox, C., \& Carmichael, P. (2003). Analysis of review of public administration omnibus survey attitudinal research. Final report.

Legrand, J.-J. \&, Staes, P. (1998). La charte de l'utilisateur des services publics. Bruxelles: Editions Labor.

Mochmann, E., Oedegaard, I. C., \& Mauer, R. (1998). Inventory of National Election Studies in Europe 1945-1995. Bergisch Gladbach: Edwin Ferger Verlag.

Moore, N., Clarke, R., Johnson, S., Seargeant, J., \& Steele, J. (1998). People and public services: A review of research into people's expectations and experiences of public services. London: The Cabinet Office, The Office for Public Management \& Acumen.

Ott, J. S., \& Shafritz, J. M. (1995). The perception of organizational incompetence. In: A. Halachmi and G. Bouckaert (eds.). The enduring challenges in public management: surviving and excelling in a changing world, San Francisco: Jossey-Bass Publishers.

Page, E., \& Wright, V. (1999). Bureaucratic elites in Western European states: a comparative analysis of top officials. Oxford: Oxford University Press.

Payne, J. M., Zovatto G., D., Carillo Flórez, F., \& Allamand Zaval, A. (2002). Democracies in development: Politics and reform in Latin America. Washington D.C.: Inter-American 
Development Bank and International Institute for Democracy and Electoral Assistance.

Peters, B. G. (1989). The politics of bureaucracy. London: Longman.

Public Service Commission, South Africa. (2003). Summary of the citizen satisfaction survey.

Rainey, H. C. (1996). Public opinion toward the civil service. In H. A. G. M. Bekke, J. L. Perry, \& T. A. J. Toonen (eds.). Civil service systems in comparative perspective (pp. 180-203). Bloomington: Indiana University Press.

Rockman, B. A. (1992). Bureaucracy, power, policy, and the state. In L. B. Hill (ed.).The state of public bureaucracy (pp. 141-170). Armonk, New York: M.E. Sharpe.

Rose, L. (1999). Citizen (re)orientations in the welfare state: from private to public citizens? In: J. Bussemaker (ed.) Citizenship and welfare state reform in Europe (pp. 131-148) London: Routledge.

Rose, L. E., \& Pettersen, P. A. (2000). The legitimacy of local government: what makes a difference? Evidence from Norway. In K. Hoggart and T. Nichols Clark (eds.).Citizen responsive government (pp. 25-66). Amsterdam: Elsevier Science.

Rouban, L. (1995). The civil service culture and administrative reform. In B. G. Peters and D. Savoie, D. (eds.) Governance in a changing environment (pp. 23-54). Montreal and Kingston: Canadian Centre for Management Development and McGill-Queen's University Press.

Ryan, N. (2000). Public confidence in the public sector. A discussion paper prepared for the Office of the Auditor General of Western Australia.

Sims, H. (2001). Public confidence in government and government service delivery. Ottawa: Canadian Centre for Management Development.

Soós, G. (2001). Indicators of local democratic governance project: concepts and hypotheses. Budapest: Local government and public service reform initiative \& Open Society Institute.

Soós, G., Tóka, G., \& Wright, G. (eds.) (2002). State of local democracy in Central Europe. Budapest: Local government and public service reform initiative \& Open Society Institute. 
Stillman, R. J. (1999). American versus European public administration: does public administration make the modern state, or does the state make public administration? In W. J. M. Kickert and R. J. Stillman (eds.) The modern state and its study: new administrative sciences in a changing Europe and United States (pp. 247-260). Cheltenham: Edward Elgar.

Swianiewicz, P. (2001). Public perception of local governments. Budapest: Local Government and Public Service Reform Initiative, Open Society Institute.

The Danish Ministry of Finance (1998). The citizens and the public sector.

The Pew Research Center for the People and the Press (1998). Deconstructing distrust: How Americans view government.

Van de Walle, S., \& Bouckaert, G. (2003). Public service performance and trust in government: the problem of causality. International Journal of Public Administration, 26(8-9): 891-913.

Vigoda, E., \& Yuval, F. (2001). The performance of Israeli public sector: A citizens survey and national assessment. Center of Organizations and Human Resource Management \& Department of Political Science, University of Haifa.

x. (2003). Belevingsmonitor ter discussie. P.M.denHaag, p. 2. 